\title{
Erratum to: Incorporation of a Probabilistic Monotonic Strain Energy Analysis to a Lifing Method
}

Onome Scott-Emuakpor • Tommy George •

Todd Letcher • M.-H. Herman Shen $\cdot$ Charles Cross

Published online: 19 January 2012

(C) ASM International 2012

Erratum to: J Fail. Anal. and Preven.

DOI 10.1007/s11668-011-9534-0

The corrected title of this article is as it appears in this erratum.

The online version of the original article can be found under doi:10.1007/s11668-011-9534-0.

O. Scott-Emuakpor $(\varangle) \cdot$ T. George $\cdot$ C. Cross

AFRL/RZTS, WPAFB, Dayton, OH 45433, USA

e-mail: onome.scott-emuakpor@wpafb.af.mil

T. Letcher - M.-H.H. Shen

Department of Mechanical and Aerospace Engineering,

The Ohio State University, Columbus, OH 43210, USA 